Jurnal IImiah AL-Jauhari (JIAJ)

Volume 3 No 1, Juni 2018

ISSN: $2541-3430$

E-ISSN: 2541-3449

Halaman 17-32

\title{
Internalisasi Nilai-Nilai Pendidikan Kewirausahaan dalam Kurikulum di SMK Salafiyah Syafi'iyah
}

\author{
Oleh: \\ Nurhamida
}

\begin{abstract}
Abstrak
Artikel ini menunjukan bahwa Internalisasi nilai-nilai pendidikan kewirausahaan pada mata pelajaran sudah diterapkan yaitu dimasukkannya nilainilai tersebut ke dalam perencanaan pembelajaran dan silabus, walaupun dalam pelaksanaan pembelajaran dengan segala keterbatasan guru yang tidak berlatar belakang pendidikan sesuai dengan mata pelajaran yang di ampuhnya, dan telah telihat perubahan sikap peserta didik di dalam pembelajaran dari penanaman lima nilai kewirausahaan kreatif dan mandiri, namun dalam hal evaluasi pembelajaran belum mengacu pada standar penilaian yang baku.
\end{abstract}

\begin{abstract}
This article shows that the internalization of the values of entrepreneurship education in subjects has been implemented, namely the inclusion of these values into learning planning and syllabus, even though the implementation of learning with all the limitations of teachers who are not educational in accordance with the subject matter is effective, and has seen changes in the attitude of students in learning from planting five values of creative and independent entrepreneurship, but in terms of evaluation of learning it has not referred to standardized assessment standards.
\end{abstract}

Kata Kunci: Internalisasi, Pendidikan Kewirausahaan, Kurikulum,

\section{Pendahuluan}

Pendidikan kewirausahaan di sekolah mulai tahun 2010 telah disosialisasikan oleh Kementerian Pendidikan Nasional di pendidikan dasar dan pendidikan menengah didasarkan pada butir-butir kebijakan nasional yang tertuang dalam RPJMN 2010-2014 yaitu peningkatan akses pendidikan yang berkualitas, terjangkau, relevan, dan efisien menuju terangkatnya kesejahteraan hidup rakyat, kemandirian, keluhuran budi pekerti, dan karakter bangsa yang kuat. Pembangunan bidang pendidikan diarahkan demi tercapainya pertumbuhan 
ekonomi yang didukung keselarasan antara ketersediaan tenaga terdidik dengan kemampuan: 1) menciptakan lapangan kerja atau kewirausahaan, 2) menjawab tantangan kebutuhan tenaga kerja. b). Penataan ulang kurikulum sekolah yang dibagi menjadi kurikulum tingkat nasional, daerah, dan sekolah sehingga dapat mendorong penciptaan hasil didik yang mampu menjawab keutuhan SDM untuk mendukung pertumbuhan nasional dan daerah dengan memasukkan pendidikan kewirausahaan, seperti yang terjadi Di SMK Salafiyah Syafi'iyah Randangan di mana kurikulumnya memasukkan pendidikan kewirausahaan sebagai mata pelajaran wajib dan melakukan penambahan jam di luar waktu pembelajaran yaitu di sore hari.

Hal ini sejalan dengan perkataan mantan Menteri Koordinator Bidang Perekonomian (Menko Perekonomian masa pemerintahan SBY) Hatta Rajasa, bahwa "wirausaha adalah kunci bagi Indonesia untuk memajukan perekonomian". Dalam rangka menciptakan wirausaha-wirausaha tersebut, salah satu caranya adalah dengan memberikan pendidikan kewirausahaan kepada peserta didik pada semua jenjang pendidikan

Pendidikan kewirausahaan merupakan aspek penting bagi perkembangan sumber daya manusia, sebab pendidikan kewirausahaan merupakan wahana atau salah satu instrumen yang digunakan bukan saja untuk membebaskan manusia dari keterbelakangan, melainkan juga dari kebodohan dan kemiskinan. Disisi lain, pendidikan kewirausahaan dipercayai sebagai wahana perluasan akses dan mobilitas sosial dalam masyarakat baik secara horizontal maupun vertikal.

Semakin maju suatu negara semakin banyak orang yang terdidik, dan banyak pula oarng yang menganggur, maka semakin dirasakan pentingnya dunia kewirausahaan pembangunan akan lebih berhasil jika ditunjang oleh entrepreneur yang dapat membuka lapangan kerja karena kemanpuan pemerintah sangat terbatas. Pemerintah tidak akan mampu menggarap semua aspek pembangunan karena sangat banyak membutuhkan anggaran belanja, persoanalia, dan pengawasan. ${ }^{1}$

Dalam mengatasi pengangguran salah satu bentuk pendekatan yang sangat strategis adalah melalui pendidikan kewirausahaan. Ciputra menawarkan alternatif solusi terhadap masalah lapangan kerja, pengangguran dan kemiskinan melalui pendidikan kewirausahaan pada pendidikan formal. Beberapa alasan yang dikemukanan antara lain adalah:Pertama, dengan penerapan nilai-nilai pendidikan kewirausahaan berarti memersiapkan generasi yang mampu menciptakan lapangan kerja serta berwirausaha. Pada gilirannya akan lahir entrepreneurentrepreneur baru yang dapat mewujudkan kesejahteraan masyarakat. Kedua, kewirausahaan dapat mengatasi secara massal terhadap pengangguran dan kemiskinan, sekaligus menjadi tangga menuju impian setiap warga masyarakat mencapai kemandirian finansial serta membangun kemakmuran. Lalu secara bersama-sama mewujudkan masyarakat makmur - sejahtera Ketiga, output pendidikan selama ini terbukti kurang mampu mengantarkan lulusan ke pasar kerja. Untuk itu diperlukan kesadaran oleh pengelola lembaga pendidikan untuk merancang dan melaklsanakan langkah-langkah penguatan bekal kompetensi dan

\footnotetext{
${ }^{1}$ Buchari Alma ,Entrepreneurship, (Bandung : Alfabeta , 2013), hlm. 1
} 
profesionalitas yang diperlukan peserta didik setelah mereka lulus melalui pengembangan jiwa entrepreneurship.

Untuk mencapai kemampuan tersebut perlu adanya Internalisasi nilai-nilai pendidikan kewirausahaan. Sehingga tercipta perilaku wirausaha pada santri atau peserta didik, seperti halnya pada observasi sebagai tahapan awal dalam penelitian ini diperoleh data dan informasi bahwa struktur kurikulum di SMK Salafiyah Syafi'iyah Randangan dengan jurusan Ternak Ruminansia berisi mata pelajaran wajib, mata pelajaran Kejuruan, Muatan Lokal, dan Pengembangan Diri.

Menurut UU No 20 Tahun 2003 tentang Sisdiknas, pasal 37, menyatakan bahwa kurikulum SMK wajib memuat tentang Pendidikan Agama, Pendidikan kewarganegaraan, Bahasa, Matematika, Ilmu Pengetahuan Alam, Ilmu Pengetahuan Sosial, Seni dan budaya, Pendidikan jasmasi dan olah raga, Keterampilan/kejuruan, dan Muatan lokal. Atas dasar itu, maka mata pelajaran wajib pada KTSP SMK terdiri atas Pendidikan Agama, Pendidikan Kewarganegaraan, Bahasa, Matematika, IPA, IPS, Seni dan Budaya, Pendidikan Jasmani Olahraga dan Kesehatan, dan Keterampilan/Kejuruan (terdiri atas Keterampilan Komputer dan Pengelolaan Informasi dan Kewirausahaan).

Mata pelajaran tersebut bertujuan untuk membentuk manusia Indonesia seutuhnya dalam spektrum manusia kerja. Oleh karena itu hal tersebut menjadi acuan bagi penulis untuk menggali sejauh mana Integrasi nilai-nilai pendidikan kewirausahaan dalam kurikulum tersebut untuk menghasilkan peserta didik yang berjiwa kewirausahaan di SMK Salafiyah Syafi'iyah Randangan Gorontalo.

Tujuan pendidikan nasional terutama yang mengarah pada perilaku entrepreneur peserta didik, selama ini belum dapat diketahui secara pasti. Hal ini mengingat pengukurannya cenderung bersifat kualitatif, dan belum ada standar nasional untuk menilainya.

Dengan demikian kewirausahaan dapat diajarkan melalui penanaman nilainilai kewirausahaan yang akan membentuk karakter dan perilaku untuk berwirausaha agar para peserta didik kelak dapat mandiri dalam bekerja atau mandiri usaha.

Salah satu komponen penting dari sistem pendidikan tersebut adalah kurikulum, karena kurikulum merupakan komponen pendidikan yang dijadikan acuan oleh setiap satuan pendidikan, baik oleh pengelola maupun penyelenggara; khususnya oleh guru dan kepala sekolah. Kurikulum tingkat satuan pendidikan tahun 2006 menekankan bahwa satuan-satuan pendidikan harus mampu mengembangkan komponen-komponen dalam kurikulum tingkat satuan pendidikan. Komponen yang dimaksud mencakup visi, misi, dan tujuan tingkat satuan pendidikan; struktur dan muatan; kalender pendidikan; silabus sampai pada rencana pelaksanaan pembelajaran.

. Dalam kurikulum di SMK Salafiyah syafi'iyah Randangan terdapat mata pelajaran kewirausahaan yang memang dirancang untuk memberikan pengetahuan tentang kewirausahaan kepada siswa. Adapun materi pelajaran kewirausahaan yang diberikan telah mencakup karakter kewirausahaan yang terkandung di dalamnya. Oleh karena itu sangat penting untuk mengembangkan Kurikulum Pendidikan Kewirausahaan agar mampu mencetak wirausaha-wirausaha baru yang handal. Hal ini tentu saja tidak menjadi tanggung jawab pemerintah semata, 
atau guru semata namun manjadi tanggung jawab bagi semua pihak yang terkait di dalamnya termasuk juga stakeholder/masyarakat.

\section{Pendidikan Kewirausahaan}

Pendidikan adalah. "Proses pengubahan sikap dan perilaku seseorang atau kelompok orang dalam usaha mendewasakan manusia melalui upaya pengajaran dan pelatihan"2

Istilah Pendidikan, dalam bahasa Inggris "education", berakar dari bahasa Latin "educare", yang dapat diartikan pembimbing berkelanjutan (to lead forth). Jika diperluas, arti etimologis itu mencerminkan keberadaan pendidikan yang berlangsung dari generasi ke generasi sepanjang eksistensi kehidupan manusia ${ }^{3}$

Makna pendidikan secara sederhana dapat diartikan sebagai usaha manusia untuk membina kepribadiannya sesuai dengan nilai-nilai di dalam masyarakat dan kebudayaannya. Dengan demikian, bagaimanapun sederhananya peradaban suatu masyarakat, di dalamnya terjadi atau berlangsung suatu proses pendidikan. Karena itulah sering dinyatakan pendidikan telah ada sepanjang peradaban umat manusia. Pendidikan pada hakikatnya merupakan usaha manusia melestarikan hidupnya.

Pendidikan dalam arti mengajarkan segala sesuatu yang bermanfaat bagi kehidupan manusia, baik terhadap aktivitas jasmania, pikiran-pikirannya maupun terhadap ketajaman dan kelembutan hati nuraninya. ${ }^{4}$

Sementara Ki Hajar Dewantara mengartikan pendidikan sebagai upaya untuk memajukan budi pekerti, pikiran serta jasmani anak, agar dapat memajukan kesempurnaan hidup dan menghidupkan anak yang selaras dengan alam dan masyarakatnya.

Lebih lanjut Ki Hajar Dewantara mejelaskan bahwa pendidikan harus mengutamakan aspek-aspek berikut: ${ }^{5}$

1. Segala alat, usaha dan cara pedidikan harus sesuai dengan kodratnya keadaan

2. Kodratnya keadaan itu tersimpan dalam adat-istiadat setiap rakyat, yang oleh karenanya bergolong-golong merupakan kesatuan dengan sifat prikehidupan sendiri-sendiri, sifat-sifat mana terjadi dari bercampurnya semua usaha dan daya upaya untuk mencapai hidup tertib damai.

3. Adat istiadat, sebagai sifat peri kehidupan atau sifat percampuran usaha dan daya upaya akan hidup tertib damai itu tiada terluput dari pengaruh zaman dan tempat.; oleh karena itu tidak tetap senantiasa berubah.

4. Akan mengetahui garis-hidup yang tetap dari sesuatu bangsa perlulah kita mempelajari zaman yang telah lalu

5. Pengaruh baru diperoleh karena bercampurgaulnya bangsa yang satu dengan yang lain, percampuran mana sekarang ini mudah sekali terjadi disebabkan adanya hubungan modern. Haruslah waspada dalam memilih

\footnotetext{
${ }^{2}$ Fajri, Em Zul, dan Ratu Aprillia Senja., Kamus Lengkap Bahasa Indonesia, ( Yokyakarta: Publisher, 2005), hlm. 254

${ }^{3}$ Suhartono, Suparlan. Filsafat Pendidikan. Cet. III, April(. Jogjakarta: Ar-Ruzz Media, 2008), hlm. 77

${ }^{4}$ Salahuddin Anas, “Filsafat Pendidikan (Bandung: CV Pustaka Setia. 2011), hlm. 19

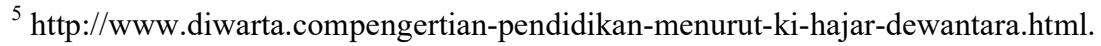

Diaklses Tanggal 16 Desember 2015
} 
mana yang baik untuk menambah kemuliaan hidup kita dan mana yang akan merugikan.

Dari definisi pendidikan di atas dapat disimpulkan bahwa pendidikan adalah proses pelatihan yang dilakukan secara terus menerus yang mampu mendewasakan dan merubah kepribadian selain juga bertambahnya ilmu pengetahuan sehingga seseorang tersebut mandiri.

\section{Hakikat Pendidikan Kewirausahaan.}

Secara sederhana arti wirausahawan (entrepreneur) adalah orang yang berjiwa berani mengambil risiko untuk membuka usaha dalam berbagai kesempatan. Berjiwa berani mengambil risiko artinya bermental mandiri dan berani memulai usaha, tanpa diliputi rasa takut atau cemas sekalipun dalam kondisi tidak pasti. Kegiatan wirausaha dapat dilakukan seorang diri atau berkelompok. $^{6}$

Kewirausahaan merupakan mata pelajaran yang dapat diajarkan di sekolah-sekolah dan telah bertumbuh sangat pesat. Transformasi pengetahuan kewirausahaan telah berkembang pada akhir-akhir ini. Demikian pula di negara kita pengetahuan kewirausahaan diajarkan di sekolah dasar, sekolah menengah, perguruan tinggi di berbagai kursus bisnis. Berikanlah para peserta didik penanaman sikap-sikap perilaku untuk membuka bisnis kemudian kita akan membuat mereka menjadi seorang wirausaha yang berbakat ${ }^{7}$. Pendidikan kewirausahaan merupakan salah satu bentuk aplikasi kepedulian dunia pendidikan terhadap kemajuan bangsanya. Di dalam pendidikan kewirausahaan diperlihatkan di antaranya adalah nilai dan bentuk kerja untuk mencapai kesuksesan.

Ada dua pendapat tentang pengertian kewirausahaan, yaitu Peter F. Drucker mengatakan bahwa kewirausahaan merupakan kemampuan dalam menciptakan sesuatu yang baru dan berbeda. Pengertian ini mengandung maksud bahwa seorang entrepreneur adalah orang yang memiliki kemampuan untuk mencipta sesuatu yang baru, atau mampu menciptakan sesuatu yang berbeda dengan sesuatu yang sudah ada sebelumnya. Sementara itu, Zimmerer mengartikan kewirausahaan sebagai suatu proses penerapan kreativitas dan inovasi dalam memecahkan persoalan dan menemukan peluang untuk memperbaiki kehidupan. ${ }^{8}$

Dari kedua pendapat di atas dapat disimpulkan bahwa kewirausahaan merupakan suatu kemampuan dalam hal menciptakan kegiatan usaha. Seorang entrepreneur harus memiliki kemampuan yang kreatif dan inovatif dalam menemukan dan menciptakan berbagai ide.

Kewirausahaan pada hakikatnya adalah sifat, ciri, dan watak seseorang yang memiliki kemauan dalam mewujudkan gagasan inovatif ke dalam dunia nyata secara kreatif. Entrepreneursip merupakan gabungan dari kreativitas, keinovasian, dan keberanian menghadapi risiko yang dilakukan dengan cara kerja keras untuk membentuk dan memelihara usaha baru.

\footnotetext{
${ }^{6}$ Muhammad Anwar, Pengantar Entrepreneurship Teori dan Aplikasiu, ( Jakarta:Prenada Media Group, 2014 ), hlm. 16

${ }^{7}$ Alma, Buchari, Entrepreneurship.( Bandung: Penerbit ALFABETA 2009), hlm.5

${ }^{8}$ Ibid, Alma, Buchari, Entrepreneurship, hlm. 8.
} 
Sejalan dengan tuntutan perubahan yang cepat pada paradigma pertumbuhan yang wajar dan perubahan ke arah globalisasi yang menuntut adanya keunggulan, pemerataan, dan persaingan, maka dewasa ini sedang terjadi perubahan paradigma pendidikan. Pendidikan kewirausahaan telah diajarkan sebagai suatu disiplin ilmu tersendiri yang independen. ${ }^{9}$ Hal itu menurut Soeharto Prawirokusuma (1997 ) dikarenakan:

a) kewirausahaan berisi body of knowledge yang utuh dan nyata, yaitu ada teori, konsep dan metode ilmiah yang lengkap

b) kewirausahaan memiliki dua konsep yaitu posisi venture start-up dan venture-growth. Ini jelas tidak masuk dalam frame work general management cources yang memisahkan management dan business ownership

c) kewirausahaan merupakan disiplin ilmu yang memiliki objek tersendiri, yaitu kemampuan untuk menciptakan sesuatu yang baru dan berbeda. kewirausahaan merupakan alat untuk menciptakan pemerataan berusaha dan pemerataan pendapatan atau kesejahteraan rakyat yang adil dan makmur.

Sementara itu kewirausahaan menurut Instruksi Presiden RI No. 4 Tahun 1995 kewirausahaan adalah semangat, sikap, perilaku, dan kemampuan seseorang dalam menangani usaha dan atau kegiatan yang mengarah pada upaya mencari, menciptakan, menerapkan cara kerja, teknologi, dan produk baru dengan meningkatkan efisiensi dalam rangka memberikan pelayanan yang lebih baik dan atau memperoleh keuntungan yang lebih besar. ${ }^{10}$

Dari uraian konsep pendidikan kewirausahaan di atas, dapat disimpulkan bahwa kewirausahaan pada dasarnya terfokus pada upaya untuk mempelajari tentang nilai, kemampuan dan perilaku seseorang dalam berkreasi dan inovasi. Oleh sebab itu, objek studi kewirausahaan adalah nilai-nilai dan kemampuan seseorang yang diwujudkan dalam bentuk sikap.

\section{Internalisasi Pendidikan Kewirausahaan dalam Islam}

Keberhasilan seorang entrepreneur dalam Islam bersifat independen. Artinya keunggulan berpusat pada integritas pribadinya, bukan dari luar dirinya. Hal ini selain menimbulkan keandalan menghadapi tantangan, juga merupakan garansi tidak terjebak dalam praktik-praktik negatif yang bertentangan dengan peraturan, baikperaturan agama ataupun peraturan teknis negara tentang usaha. Integritas entrepreneur Muslim terlihat dalam sifat-sifatnya, antara lain: ${ }^{11}$
a. Takwa, tawakal, zikir, dan bersyukur
b. Motivasinya bersifat vertical dan horizontal
c. Niat suci dan ibadah
d. Azam "bangun lebih pagi"
e. Selalu berusaha meningkatkan ilmu dan keterampilan

\footnotetext{
${ }^{9}$ Soeharto Prawirokusuma, dalam Muhammad Anwar, Pengantar Entrepreneurship Teori dan Aplikasi, ( Jakarta: Prenadamedia Group, 2014), hlm. 15

${ }^{10}$ Basrowi, Entrepreneurship untuk Perguruan Tinggi, (Bogor: Ghalia Indonesia, 2011), hlm. 2

${ }^{11}$ Muhammad Anwar,Pengantar entrepreneurship teori dan aplikasi, hlm. 129-132
} 


\section{f. Jujur}

g. Suka menyambung silaturahmi

h. Menunaikan zakat, infak, dan sedekah

i. Puasa, salat sunat, dan salat malam

j. Mengasuh anak yatim

Sebagai konsekuensi pentingnya kegiatan kewirausahaan, Islam menekankan pentingnya pembangunan dan penegakan budaya kewirausahaan dalam kehidupan setiap Muslim. Budaya kewirausahaan Muslim itu bersifat manusiawi dan religious, berbeda dengan budaya profesi lainnya yang tidak menjadikan pertimbangan agama sebagai landasan kerjanya. Dengan demikian, pendidikan entrepreneur Muslim akan memiliki sifat-sifat dasar yang mendorongnya untuk menjadi pribadi yang kreatif dan andal dalam menjalankan usahanya.

Jiwa entrepreneur seseorang bukanlah merupakan faktor keturunan, namun dapat dipelajari secara ilmiah dan ditumbuhkan bagi siapa pun juga. Pendidikan kewirausahaan dapat dilakukan apabila pendidik sudah memiliki jiwa entrepreneur yang tinggi. Yang penting dan yang utama dari pendidikan kewirausahaan adalah semangat untuk terus mencoba dan belajar dari pengalaman. "gagal itu biasa, berusaha terus itu yang luar biasa", mungkin seperti itulah gambaaran yang harus dikembangkan oleh manusia-manusia Indonesia agar tetap eksis dalam pertarungan bisnis yang semakin transparan dan terbuka.

\section{Kegiatan Kewirausahaan menurut Pandangan Islam}

Konsekuensi pentingnya kegiatan kewirausahaan, Islam menekankan pentingnya pembangunan dan penegakan budaya kewirausahaan dalam kehidupan setiap Muslim. Budaya kewirausahaan Muslim bersifat manusiawi dan religious, berbeda dengan budaya profesi lainnya yang tidak menjadikan pertimbangan agama sebagai landasan kerjanya. Dalam QS. At-Taubah (9): 105, Allah swt. Berfirman:

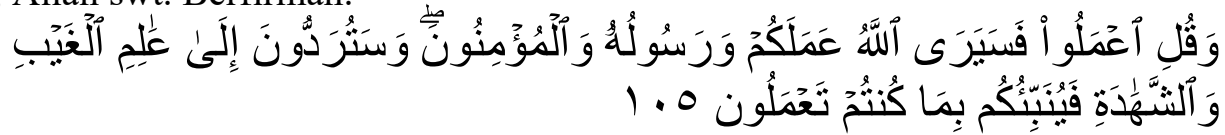

Terjemahnya:

"Dan Katakanlah: "Bekerjalah kamu, maka Allah dan Rasul-Nya serta orangorang mukmin akan melihat pekerjaanmu itu, dan kamu akan dikembalikan kepada (Allah) Yang Mengetahui akan yang ghaib dan yang nyata, lalu diberitakan-Nya kepada kamu apa yang telah kamu kerjakan. ,"12

Oleh karena itu, apabila salat telah ditunaikan, maka bertebaranlah kamu di muka bumi dan carilah karunia ( rezeki) Allah. Dalam QS. Al-Jumuah (62) : 10 Allah berfirman:

\footnotetext{
${ }^{12}$ Departemen Agama RI, al-Quran dan Terjemahynya, ( Jakarta : Proyek Pengadaan Kitab Suci al-Quran, 2006 ), hlm. 200
} 


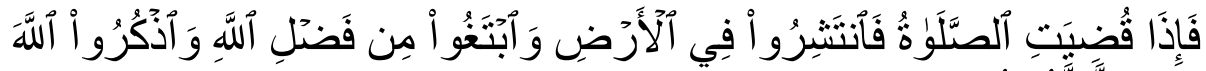

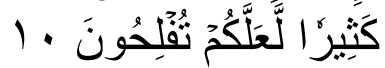

Terjemahnya:

'Apabila telah ditunaikan shalat, maka bertebaranlah kamu di muka bumi; dan carilah karunia Allah dan ingatlah Allah banyak-banyak supaya kamu beruntung. ",13

Berdasarkan beberapa definisi dan hasil penelitian terdahulu yang telah diungkapkan maka penelitian ini dapat disusun suatu kerangka konseptual tentang Internalisasi Pendidikan Kewirausahaan dalam Kurikulum di SMK Salafiya Syafi'iyah Randangan Gorontalo sebagai berikut.

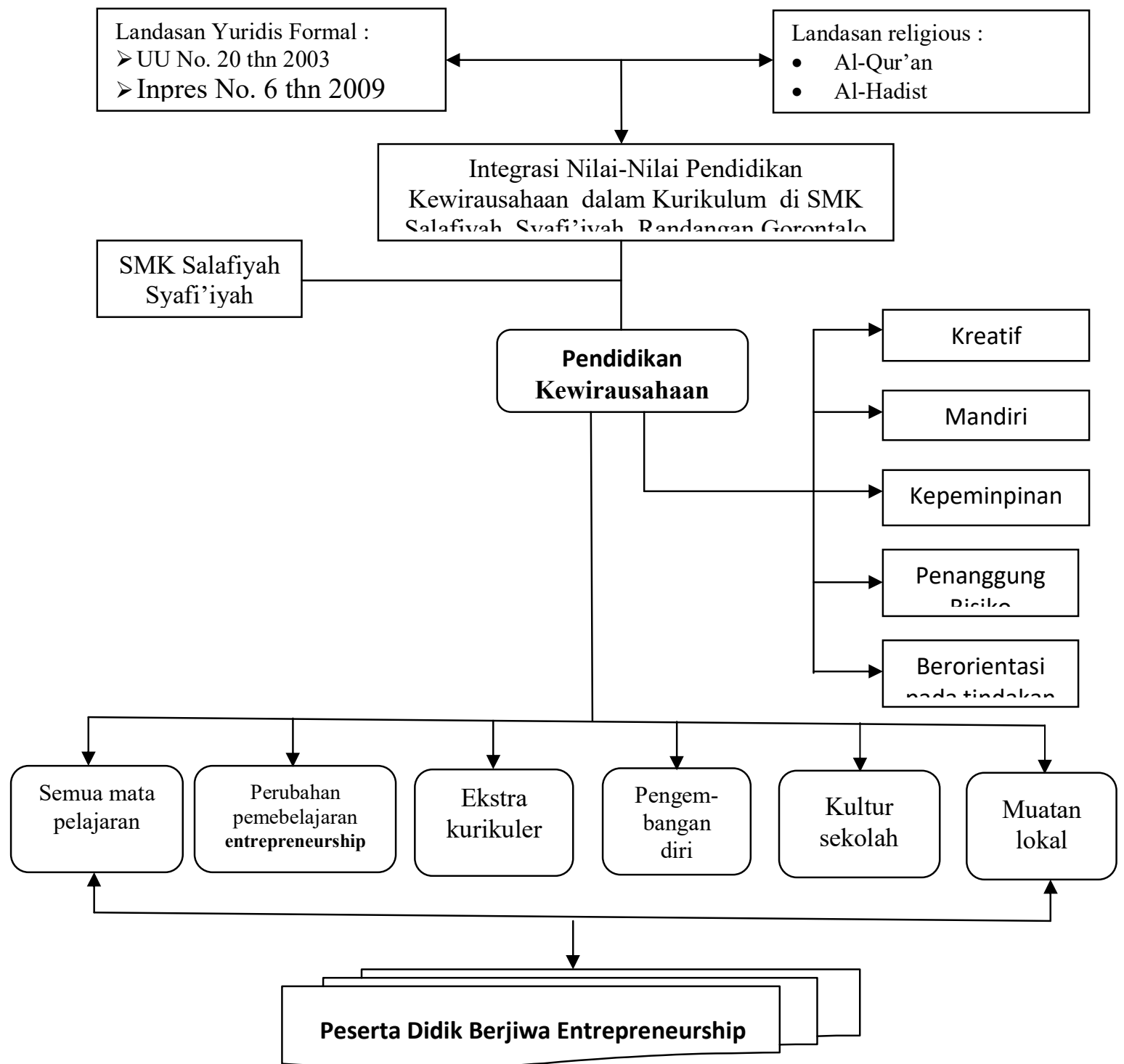

${ }^{13}$ Ibid. hlm. 234 


\section{A. Nilai-Nilai Pendidikan Kewirausahan}

Dalam proses belajar mengajar dibutuhkan suatu strategi untuk memudahkan pendidik maupun peserta didik dalam memahami dan mengintrepretasikan suatu ilmu khususnya dalam bidang pendidikan kewirausahaan yang diterapkan di sekolah SMK sesuai dengan kurikulum yang diharapkan dengan menginternalisasi lima nilai-nilai pokok kewirausahaan diantaranya nilai kreatif, mandiri, kepeminpinan, berani menanggun risiko dan beriorentasi pada tindakan dengan penjelasan sebagai berikut:

\section{Nilai Kreatif}

Hasil penelitian menunjukan bahwa pendidikan kewirausahaan di sekolah SMK Salafiyah syafi'iyah Randangan terintegrasi di dalam proses pembelajaran yang diinternalisasikan ke dalam nilai kreatif dan akan terbentuk karakter wirausaha dan pembiasaan nilai-nilai kewirausahaan ke dalam tingkah laku peserta didik sehari-hari melalui proses pembelajaran baik yang berlangsung di dalam kelas maupun di luar kelas pada semua mata pelajaran. Langkah internalisasi ini dapat dilihat pada saat guru menyampaikan materi, melalui metode pembelajaran maupun melalui sistem penilaian. Sekolah juga sebaiknya menyediakan alat-alat praktik yang lain,sehingga saat guru mengajarkan materi khusus praktik yang menggunakan alat tidak mengalami kesulitan, di luar dari yang telah siswa buat sendiri dari hasil kreativitasnya.

\section{Nilai Kemandirian}

Hasil penelitian menunjukan bawa dengan adanya nilai-nilai kemandirian yang ditanamkan pada diri peserta didik melalui pendidikan kewirausahaan di sekolah telah diinternalisasikan ke dalam semua mata pelajaran maka peserta didik dapat berperilaku mandiri dalam berpikir dan bertindak kreatif maupun inovatif dalam menyelesaikan berabagai masalah yang dihadapinya sebagaimana wawancara yang dilakukan kepada salah seorang guru disekolah salafiyah syafi'iyah Randangan yakni terdapat beberapa perubahan-perubahan yang sebelumnya sangat mengandalkan guru, namun dengan adanya nilai-nilai kemandirian tersebut setiap peserta didik sudah mampu berpikir dan bertindak kreatif dengan penuh inisiatif serta percaya diri untuk memperoleh kepuasan dari usahanya, seperti peserta didik dapat melakukan praktek langsung dengan menghasilkan suatu produk, dan kerajinan-kerajinan tangan lainnya. ${ }^{14}$

\section{Nilai Kepemimpinan}

Kepemimpinan merupakan suatu kemampuan seseorang untuk tidak bergantung dengan orang lain serta bertanggung jawab atas apa yang dilakukannya, dan hal tersebut sejalan dengan penjelasan dari informan yang merupakan salah seorang guru SMK Salafiyah safi'iyah Randangan Gorontalo pada saat peneliti mengadakan wawancara dan hasilnya sebagai berikut:

\footnotetext{
${ }^{14}$ Agus Riyadi, guru, wawancara tanggal 26 September 2015
} 
"Nilai kepemimpinan merupakan dorongan kepada peserta didik untuk memiliki karakter seorang pemimpin, jadi setiap peserta didik telah diajarkan untuk menjadi seorang pemimpin seperti hari senin peserta didik dapat melaksanakan upacara bendera, kegiatan pramuka dan di dalam kelas peserta didik selalu diajarkan membentuk kelompok diskusi sehingga dengan sendirinya peserta didik telah diajarkan tentang bagaimana menjadi seorang pemimpin". 15

Mengacu pada pernyataan informan di atas bahwa kepemimpinan merupakan faktor kunci bagi peserta didik dalam melakukan kegiatan -kegiatan sekolah dan mudah bergaul terhadap lingkungannya, mampu bekerja sama, mengkoordinir, dan mengoreksi maupun menegur teman yang dianggap keliru demikian pula datang di sekolah tepat pada waktunya, semangat kerja yang tinggi, dan jujur.

\section{Nilai Berani Menanggung Risiko}

Berani menanggung risiko dalam pendidikan kewirausahaan yang diterapkan di sekolah khususnya di sekolah Salafiyah Syafi'iyah Randangan Gorontalo yang selanjutnya peneliti melakukan wawancara kepada salah seorang informan selaku wakil kepala sekolah bagian kurikulum dan hasil wawancaranya sebagai berikut:

"Berani menanggung risiko dalam hal ini peserta didik menyukai tugas yang menantang yang diberikan oleh guru dan berani menerima akibat dari tugas tersebut, seperti berjualan produk olahan susu sapi dan kripik jagung dikalangan santri dan kegiatan bulanan pondok yakni kegiatan majelis taklim setiap malam jum'at yang di pondok pesantren salafiyah syafi'yah dan terkadang produk yang dijual tidak semuanya laku namu tetap berusaha keras untuk meningkatkan kualiats agar penjualan produk dapat ditingkatkan". ${ }^{16}$

Satu hal yang harus dimiliki peserta didik adalah suatu keberanian untuk mengambil keputusan yang siap dengan risikonya dan keyakinan yang kuat tentang keputusan apapun yang diambilnya pasti mengandung risiko yang harus ditanggung.

\section{Berorientasi pada Tindakan}

Berorientasi pada tindakan merupakan suatu kemampuan seseorang untuk tidak bergantung dengan orang lain serta bertanggung jawab atas apa yang dilakukannya, dan hal tersebut sejalan dengan penjelasan dari informan yang merupakan salah seorang guru SMK Salafiyah Safi'iyah Randangan Gorontalo pada saat peneliti mengadakan wawancara dan hasilnya sebagai berikut

"Memberikan kesempatan kepada peserta didik untuk menerapkan gagasannya seperti yang telah dijelaskan diatas bahwa saat anak diberi tugas dan anak tersebut senang melakukannya, dan peserta didik dapat

\footnotetext{
${ }^{15}$ Solehuddin, Wawancara tanggal 26 September 2015

${ }^{16}$ Agus Riyadi, wakil kepala sekolah bagian kurikulum, wawancara tanggal, 26 September 2015
} 
mewujudkan gagasan dengan tindakan, misalnya diminta untuk membuat alat-alat peraga dan mereka langsung mewujudkannya dengan mencari bahan-bahannya". ${ }^{17}$

Peserta didik harus mempelajari bagaimana menghadapi risiko, ketidakpastian, dan keterbatasan dalam setiap masalah yang dihadapi dan bagaimana mengambil suatu tindakan atau keputusan dengan cepat agar dapat menggunakan kesempatan sebaik-baiknya seperti seorang entrepreneur yang ingin maju dalam bisnisnya, maka harus dapat mengandalkan intuisi, ide-ide yang penuh kreatif dan inovatif.

\section{B. Faktor Pendukung Internalisasi Nilai-Nilai Pendidikan Kewirausahaan}

Dalam proses pembelajaran di kelas guru membutuhkan pendukung berupa media sebagai sumber belajar. Adapun media yang digunakan diantaranya adalah: white board, LCD, buku paket, internet dan lain sebagainya. Sedangkan untuk sumber materi praktikan menggunakan beberapa buku acuan yang tersedia di perpustakaan, buku pegangan guru, kurikulum dan dari internet serta laboratorium tempat praktik. Sesuai dengan hasil pengamatan penulis di lapangan, bahwa di SMK Salafiyah Syafi'iyah Randangan Gorontalo semua fasilitas ini di gunakan oleh guru sebagai alat pendukung pada saat proses pembelajaran berlangsung. Selain itu faktor pendukung penginternalisasian nilainilai kewirausahaan adalah semangat belajar yang tinggi dari peserta didik, ruang belajar yang nyaman, suasana belajar yang kondusif, metode pembelajaran yang tepat, media atau alat belajar yang lengkap dan berfungsi baik, pengajar yang pakar dibidangnya, dan adanya keteladanan yang baik dan berperilaku oleh para pendidik. Dengan adanya pendukung tersebut tentunya akan mendukung internalisasi nilai-nilai pendidikan kewirausahaan dengan tersedianya fasilitas yang dibutuhkan oleh guru dalam proses pembelajaran, berarti penerapan internalisasi nilai-nilai pendidikan kewirausahaan di sekolah dapat tercapai dengan baik dan benar sesuai harapan dan tujuan diberlakukannya sebuah kurikulum.

\section{Faktor Penghambat Internalisasi Nilai-Nilai Pendidikan Kewirausahaan}

Pendidikan kewirausahaan di sekolah jika terinternalisasi di setiap mata pelajaran maka perlu dikembangkan, dieksplisitkan, dikaitkan dengan konteks kehidupan sehari-hari. Dengan demikian, pembelajaran yang berwawasan pendidikan kewirausahaan tidak hanya pada tataran kognitif, tetapi menyentuh pada internalisasi, dan pengamalan nyata dalam kehidupan peserta didik seharihari di masyarakat. ${ }^{18}$

Hal tersebut sebagaimana yang di jelaskan oleh informan secara singkat saat diwawancarai, bahwa factor penghambat yang sering dihadapi dalam internalisasi nilai-nilai pendidikan kewirausahaan adalah sebagai berikut:

\footnotetext{
${ }^{17}$ Gunawan, guru, wawancara tanggal, 26 September 2015

${ }^{18}$ Budi Wahyono,." Permasalahan Pendidikan Entrepreneurship di Indonesia dan Bagaimana Solusinya", dalam www.pendidikanekonomi.com, diakses tanggal 26 Desember 2015
} 
"Seorang pengajar butuh kesabaran dalam menyampaikan materi karena tingkat pemahaman peserta didik berbeda-beda sehingga materi yang disampaikan harus dilakukan secara berulang-ulan akibatnya materi seringkali tertinggal dari hal yang telah direncanakan". ${ }^{19}$

Dengan tingkat pemahaman peserta didik yang berbeda-beda untuk memahami pelajaran maka seorang guru dalam menyajikan materi perlu adanya keterampilan atau kompetensi untuk memahami secara khusus setiap peserta didik dalam mentransfer materi karena setiap pesarta didik dalam memahami setiap materi yang diberikan ada yang cepat menerima materi yang disampaikan oleh guru dan adapula yang lambat sehingga seorang guru dibutuhkan kesabaran dalam proses pembelajaran.

Secara singkat hal lain juga disampaikan informan selaku guru disaat peneliti menemui di ruang kepala sekolah bahwa hambatan sering muncul dalam internalisasi nilai-nilai pendidikan kewirausahaan di sekolah khususnya di SMK Salafiyah Syafi'iyah sebagai berikut:

Dalam internalisasi nilai-nilai pendidikan kewirausahaan di sekolah yang menjadi penghambatnya adalah padatnya jam mengajar yang dibebankan kepada guru, kelas yang tidak sebanding dengan jumlah siswa, ruangan praktek terbatas dan keterbatasan alat penunjang mata pelajaran serta belum ada mitra kerja dari luar sekolah. ${ }^{20}$

Bahwa faktor penghambat selalu ada dalam setiap kegiatan seperti padatnya jam mengajar yang diampuh oleh seorang guru mengangkibatkan guru tidak mampu mengajar secara maksimal sehingga peserta didik tidak dapat menerima materi dengan baik, hal tersebut merupakan hambatan dalam proses pembelajaran di sekolah khususnya dalam menginternalisasi nilai-nilai pendidikan kewirausahaan di sekolah perlu adanya guru yang profesional, demikian pula faktor penghambat dalam menerapkan internalisasi nilai -nilai kewirausahaan di sekolah adalah fasilitas atau ruangan untuk melakukan praktik kewirausahaan sangat terbatas dan mitra dari pihak lain untuk mengembangkan usaha kreativitas dan produktivitas siswa tidak dapat dikembangkan tetapi hanya sebatas praktik.

\section{Kesimpulan}

Kecenderungan sikap atau nilai-nilai kewirausahaan yang dimiliki siswa berdasarkan hasil tes menunjukkan angka yang relatif belum optimal hal ini meng-indikasikan bahwa sikap kewirausahaan siswa belum terbentuk dengan baik, hasil analisis kurikulum yang digunakan oleh SMK Salafiyah Syafi'iyah Randangan menunjukkan bahwa kompetensi yang ingin dicapai dengan sajian materi pelajaran kewirausahaan, menunjukkan masih sangat minim materi yang diarahkan pada pembentukan sikap/nilai namun lebih kepenambahan wawasan

\footnotetext{
${ }^{19}$ Siti maria Ulfa, guru, wawancara pada tanggal 26 September 2015

${ }^{20}$ Agus Riadi, Guru, wawancara pada tanggal 26 September 2015
} 
kewirausahaan dan demikian pula bahwa keterampilan mengelola bisnis, serta bahan ajar yang dipergunakan sebagai referensi guru untuk mata pelajaran kewirausahaan sangat terbatas, hal tersebut menimbulkan keterbatasan alokasi waktu sebab, SMK Salafiyah Syafi'iyah Randangan belum memiliki sarana dan fasilitas yang memadai terutama dalam membuat IB ( Inseminasi Buatan).

Internalisasi nilai-nilai kewirausahaan ke semua mata pelajaran telah diterapkan namun belum maksimal, terbukti sudah dimasukkannya nilai-nilai tersebut ke dalam perencanaan pembelajaran seperti memasukkan nilai yang di internalisasi ke dalam silabus ataupun RPP, begitupula dalam pelaksanaan pembelajaran dengan segala keterbatasan guru yang tidak berlatar belakang pendidikan kewirausahaan sehingga sedikit sulit dalam menentukan nilai yang akan diinternalisasikan dengan materi yang diajarkan, Selain itu evaluasi pembelajaran yang dilaksanakan oleh guru masih sederhana yaitu dalam hal nilai setelah pembelajaran ada evaluasi yang diberikan kepada peserta didik hanya berbentuk nilai yang telah di tetapkan sendiri oleh setiap guru mata pelajaran yang terangkum dalam absen guru tanpa membuat instrumen atau desain evaluasi seperti pemberian tugas dengan essai dan pilihan ganda yang belum mengacu pada standar penilaian diantaranya dengan membuat instrument.

Adapun yang manjadi kendala dalam internalisasi nilai-nilai pendidikan kewirausahaan di SMK Salafiyah Syafi'iyah Randangan yaitu keterlambatan peserta didik di ruang belajar, tingkat pemahaman peserta didik yang berbedabeda, guru yang tidak sesuai dengan latar belakang pendidikan, metode pembelajaran yang dilakukan guru yang tidak tepat, serta tidak bervariasi yang mengakibatkan peserta didik jenuh saat pembelajaran, ketersediaan sarana dan prasarana praktik yang minim, serta keterbatasan modal dari sekolah dalam mendukung praktik siswa. 


\section{DAFTAR PUSTAKA}

Alma, Buchari, Kewirausahaan, Bandung : Penerbit Alfabeta, 2009.

Anas, Salahuddin, “Filsafat Pendidikan, Bandung: CV Pustaka Setia, 2011.

Anwar, Muhammad, Pengantar Kewirausahaan Teori dan Aplikasi, Jakarta: Prenadamedia Group, 2014.

Arikunto, Suharsimi, Prosedur Penelitian; Suatu Pendekatan Praktek. Jakarta: Rineka Cipta, 1999.

Astamoen, Moko P., Entrepreneurship dalam Perspektif Kondisi Bangsa Indonesia, Bandung: Alfabeta, 2005.

Badudu, Kamus Umum Bahasa Indonesia, Jakatra: Pustaka Sinar Harapan, 1994.

Basrowi, Kewirausahaan untuk Perguruan Tinggi, Bogor: Ghalia Indonesia, 2011.

Bisri, Cik Hasan, Penuntutan Penyusunan Rencana Penelitian , Jakarta: PT Rajagrafindo Persada, 2003)

Bogdan, Robert dan Steven J. Tailor, Dasar-Dasar Penelitian Kualitatif. terjemahan A. Khosin Afandi, Surabaya: Usaha Nasional, 1993.

Ciputra, dalam Rianto Nugroho,Memahami Latar Belakang Pemikiran Entreprenership Ciputra, Jakarta: PT Elex Media Komputindo, 2010.

Danim, Sudarwam, Menjadi Peneliti Kualitatif. Bandung: Pustaka Setia, 2002

Daryanto, Kewirausahaan, Yokyakarta: Gava Media, 2013

Departemen Agama RI, al-Quran dan Terjemahnya, Jakarta : Proyek Pengadaan Kitab Suci al-Quran, 2006.

Gay,L.R, Educational Research: Competencies for Analysis and Applications, Toronto: Merril Pubhlishing Company, 1987.

Halim, Abdul, Model Pengembangan Kewirausahaan Sekolah Menengah Kejuruan (Smk) Dalam Menciptakan Kemandirian Sekolah, Jurnal, Riptek, Vol.4, No.1, Tahun 2010 
Hasanah, Muwahidah Nur," Implementasi Pendidikan Kewirausahaan dalam Perspektif Islam Di Smk Muhammadiyah 2 Ngawi Jawa Timur”,Tesis, Program Pascasarjana Universitas Muhammadiyah Surakarta, 2013/2014

Kasmir, Kewirausahaan, Ed.Revisi, Jakarta: Rajawali Pers, 2014.

Kepmendiknas. Bahan Pelatihan Penguatan Metodologi Pembelajaran Berdasarkan Nilai-nilai Budaya untuk Membentuk Daya saing bangsa. Pendidikan Kewirausahaan. Jakarta: Pusat Kurikulum Muslimin Ibrahim, dkk.. Pembelajaran Kooperatif(. Surabaya: University Press 2010)

Marja, Upaya Pembelajaran Nilai Kewirausahaan dalam Menumbuhkembangkan Kemandirian Nelayan, Tesis: IKIP Bandung, 1998.

Mathew B.Miles and A.Michael Huberman, Qualitative Data Analysis. London : Sage Publication,Inc.

Muliani, Endang, Jurnal Ekonomi dan Pendidikan, vol. 8 Nomor 1, April 2011

Mulyadi, Implementasi Nilai Manajemen Qalbu di Pondok Pesantren Dar Al Tawhid, Bandung: Tesis SPS UPI, 2007.

Moleong, Lexy J, Metodologi Penelitian Kualitatif; Edisi Revisi, Bandung : PT Remaja Rosdakarya, 2014.

Nata, Abuddin, Kapita Selekta Pendidikan Islam, Jakarta: PT. Raja Grapindo Persada, 2012

Prawirokusuma, Soeharto, dalam Muhammad Anwar, Pengantar Kewirausahaan Teori dan Aplikasi, Jakarta: Prenadamedia Group, 2014.

Siswanto, Ibnu, Faktor Pendukung Dan Penghambat Pelaksanaan Unit Produksi, Jurnal Penelitian dan Pengabdian Kepada Masyarakat (PPKM) LP3M-PB UNSIQ Wonosobo Volume 2 No 2 Mei 2015 ISSN 2354-869X

Susilo, Muhammad Joko, Kurikulum Tingkat Satuan Pendidikan Manajemen Pelaksanaan dan Kesiapan Sekolah Menyongsongnya, Yogyakarta : Pustaka Pelajar, 2007.

Usman, Husaini, Peran Baru Administrasi Pendidikan dari Sentralistik Menuju Sistem Desentralistik, Artikel dalam Jurnal Ilmu Pendidikan, Jakarta: Pebruari 2001, Jilid 8 No.1

Usman, Husaini \& Nuryadin Eko Raharjo, "Model Pendidikan Karakter Kewirausahaan di Sekolah Menengah Kejuruan”Jurnal Pendidikan Teknologi dan Kejuruan,Vol.21 Nomor 2,Oktober 2012. 
Wiratno, Siswo,pelaksanaan pendidikan kewirausahaan, Jurnal Pendidikan dan Kebudayaan, Vol. 18, Nomor 4, Desember 2012

Winarno, Agung, Pendidikan Kewirausahaan Smk Dengan K-13: Persepektif Guru Dan Sekolah, Seminar Nasional Ekonomi Manajemen Dan Akuntansi (Snema) Fakultas Ekonomi Universitas Negeri PadangSnema2015.

Yulianingsih , Wiwiw," Efektifitas Program Pendidikan Kewirausahaan Masyarakat melahi Model Enam Fitur Inti Sebagai Upaya Menumbuhkan Wirausahadi Wilayah Binaan Upt Skb Cerme Kabupaten Gresik”,Tesisi Fakultas Ilmu Pendidikan Universitas Negeri, Surabaya, 2014.

Zubaedi, Isu-Isu Baru dalam Diskursus Filsafat Pendidikan Islam dan Kapita selekta Pendidikan islam,, Yogyakarta: Pustaka Pelajar, 2012. 